\title{
Perancangan Ilustrasi sebagai Edukasi tentang Polusi Akibat Limbah Cair Produksi Fashion
}

\author{
Annetta Dewi Wijaya ${ }^{1^{*}}$, Obed Bima Wicandra ${ }^{2}$, Asthararianty ${ }^{3}$ \\ 1,2,3 Program Studi Desain Komunikasi Visual, Fakultas Seni dan Desain \\ Universitas Kristen Petra, Jl. Siwalankerto No.121-131 Surabaya \\ "Penulis korespondensi; E-mail: annettadw13@gmail.com
}

\begin{abstract}
Abstrak
Meski dibutuhkan dalam kehidupan sehari-hari, fashion sebagai sebuah industri memiliki dampak yang sangat buruk pada lingkungan. Khususnya tahapan produksi fashion yaitu dyeing menghasilkan banyak sekali limbah cair yang mencemari perairan, sehingga berdampak buruk pada hewan dan tanaman, dan juga bisa menimbulkan penyakit pada manusia. Tapi masyarakat masih kurang tahu dan tidak peduli terhadap masalah ini sehingga mengonsumsi fashion tanpa dipikirkan dahulu. Perancangan ini diharapkan dapat meningkatkan kepedulian masyarakat sehingga mendorong mereka untuk mengubah kebiasaan konsumsi fashion-nya.
\end{abstract}

Kata kunci: Ilustrasi, Komik, Polusi, Fesyen.

\begin{abstract}
Although essential to everyday life, fashion as an industry has terrible effects on the environment. In particular, the dyeing stage of fashion production produces a huge amount of liquid waste that pollutes water, hence having a bad impact on aquatic life, as well as causing various diseases in humans. However, people still do not know and care much about the topic, and so they consume fashion without careful consideration. This design is aimed to increase people's concern to push them to change their habits in fashion consumption.
\end{abstract}

Keywords: Illustration, Comic, Pollution, Fashion.

\section{Pendahuluan}

Fashion merupakan sebuah bagian yang sangat penting dalam kehidupan masyarakat. Namun, sebagai sebuah industri fashion juga memiliki dampak negatif yang sangat besar terhadap lingkungan hidup. Dari produksi bahan mentahnya hingga produksi pakaian, sampai setelah pakaian tersebut selesai dipakai, industri ini menghasilkan limbah dalam jumlah yang sangat banyak, dan berpengaruh besar terhadap kondisi lingkungan. Thomas (2019) menyatakan bahwa estimasi dari The World Bank menyatakan bahwa sektor industri fashion ini bertanggung jawab akan hampir $20 \%$ polusi air dari limbah seluruh industri setiap tahunnya.

Pencemaran air ini berupa dampak dari proses pengolahan tekstil. Dari semua proses pengolahan, yang menjadi fokus utama dalam produksi pakaianadalah pewarnaan kain (dyeing). Hethorn \& Ulasewicz (2015) menyatakan hal ini karena dyeing adalah cara paling mudah, murah dan pasti untuk mengubah penampilan pakaian agar menarik perhatian konsumen.
Akibatnya, dyeing tentu hampir selalu dilakukan dalam pengolahan kain. Proses pewarnaan kain adalah mencelupkan kain ke dalam air berisi dye agar bereaksi dan diserap oleh fiber kain. Seberapa banyak reaksi ini disebut dengan istilah fixation. Hal ini bergantung kepada berapa banyak dye yang benarbenar terserap dalam kain setelah pencucian (Koul, 2008), sedangkan dye yang masih tersisa men-jadi limbah cair. Limbah berupa 200.000 ton pewarna kain dibuang ke sungai dan laut setiap tahunnya (Fashion's Environmental Impact, 2017). Proses dyeing menghasilkan bahan kimiadalam limbah cair yang seringkali dibuang tanpa diolah terlebih dahulu. Beberapa dari bahan kimia yang terkandung di dalamnya beracun atau berbahaya untuk manusia.

Hal ini terutama berlaku untuk pewarna sintetis. Thomas (2019) menyatakan contohnya dalam pembuatan indigo sintetis, yang biasanya digunakan untuk mewarna kain denim. Bebe-rapa pabrik di Cina memproduksi sebagian besar dari dye indigo sintetis yang diguna- 
kan sekarang. Pembuatannya menggunakan bahan kimia yang disebut aniline. The Environmental Protection (EPA) mengklasifikasikan aniline sebagai Grup $\mathrm{B} 2$, kemungkinan zat karsinogen untuk manusia, artinya bahan kimia ini dapat menyebabkan kanker dan US Centers for Disease Control and Prevention juga menyatakan bahwa aniline sangat beracun untuk kehidupan bawah air. Laporan terbaru menyatakan bahwa $2 / 3$ residu aniline berakhir selain di limbah cair yang kemudian mencemari sungai, danau, dan perairan lainnya, dan juga pada para pekerja, dan di udara yang dihiruppekerja. 1/3 sisa residunya tertanam dalam pakaian denim yang dijual di tokotoko, yang kemudian kita pakai.

Di Indonesia sendiri dampak pencemaran air ini sudah dapat terlihat dari kondisi sungai Citarum di Jawa Barat. Di tahun 2018, 50\% atau 444 perusahaan tekstil di Jawa Barat berada di daerah aliran sungai (DAS) Citarum. Namun, berdasarkan data pemerintah, hanya 380 yang memiliki instalasi pengolahan air limbah(IPAL). Sisanya membuang limbah cair langsung tanpa diolah. Akibatnya, sungai Citarum dikenal sebagai sungai terkotor di Indonesia (Lebih dari 64 Industri Tekstil diduga Buang Limbah ke Citarum, 2018). Padahal sungai ini merupakan sumber air bersih $80 \%$ warga DKI Jakarta dan juga mengairi 420.000 ha sawah, dan juga menjadi penghasil 1.880 MW listrik untuk Jawa dan Bali. Tapi keadaannya sekarang, limbah cair industri yang mencemari DAS Citarum, termasuk limbah tekstil, adalah sebanyak 349.000 ton per hari (Satrianegara, April 6, 2018). Di Surabaya pun dampak pencemaran ini sudah mulai dapat dirasakan. Setelah dilakukan inspeksi menda-dak pada tanggal 28 Desember 2017 di wilayah Kali Surabaya, ditemukan satu pabrik pewarna kain Gaweredjo yang membuang limbah cair tanpa diolah sehingga banyak ikan yang mati (Pabrik Pewarna Kain Gaweredjo Diduga Cemari Kali Surabaya, 2017).

Masyarakat Surabaya pada umumnya mengonsumsifashion tanpa memikirkan dampakdampak tersebut, atau mungkin belum memiliki kepedulian mengenai seberapa parahnya dampak polusi dari limbah industri fashion. Karena itu dengan mengangkat topik polusi limbah industri fashion dalam perancangan ini, harapannya dapat menjadi sebuah edukasi untuk masyarakat Surabaya agar dapat menyadari betapa parahnya dampak produksi baju yang mereka pakai, sehingga bisa men- dorong masyarakat untuk mengurangi konsumsi baju baru dan memperhatikan cara produksi baju yang dibeli.

Perancangan serupa yang juga mengambil topik pengaruh fashion terhadap lingkungan adalah Perancangan Kampanye Sosial Pengolahan LimbahTekstil Rumah Tangga yang Efisien dan Bertanggung Jawab oleh Cherlita Christanti pada tahun 2019. Perancangan tersebut berupa kampanye donasi pakaian sebagai upaya mengatasi limbah fashion rumah tangga. Perbedaannya dengan perancangan ini adalah objek perancangan sebelumnya merupakan limbah fashion rumah tangga, sedangkan perancangan ini mengambil topik limbah cair industri fashion. Perbedaan lain yaitu medianya, sebelumnya berupakampanye, sedangkan media perancangan ini adalah ilustrasi (komik).

\section{Metode Perancangan}

Metode pengumpulan data yaitu dari berbagai sumber buku dan internet. Selain itu untuk mendapatkan data tentang keadaan sasaran perancangan, digunakan survei Google Form dan observasi terhadap sasaran perancangan. Analisis data menggunakan metode analisis kualitatif yaitu metode $5 \mathrm{~W}+1 \mathrm{H}$.

\section{Identifikasi dan Analisis}

\section{Ilustrasi}

Kata ilustrasi diambil dari bahasa Latin illustrare yang artinya menerangkan. Jadi untuk mengilustrasi artinya membuat sesuatu menjadi lebih jelas (vocabulary.com, n.d.). Menurut Houston (2016), ilustrasi adalah sebuah gambar yang menyampaikan atau membantu menyampaikan suatu konsep. Contohnya, ilustrasi sering menyertai sebuah artikel,di mana ilustrasi itu bisa memiliki 3 tujuan. Tujuan ini antara lain untuk mengkomunikasikan informasi dengan lebih baik dengan cara memperkuat konsep artikel, atau untuk meringkas informasi artikel, atau bisa juga untuk menarik perhatian pembaca dan mendorong mereka untuk membaca artikel tersebut.

Menurut Houston (2016), ada beberapa genre dalam ilustrasi yaitu editorial, advertising, fashion, ilustrasi teknis, dan komik/novel grafis.

\section{Komik Sebagai Media Ilustrasi}

Menurut Scott McCloud (1994), komik adalah gambar yang disandingkan dan gambar lain 
yang disusun dalam urutan yang disengaja, untuk menyampaikan informasi dan/atau untuk membuat suatu respons estetik kepada pembaca.

\section{Komik Digital}

Hingga sekarang, komik sudah mengarah ke duniadigital. Komik online pertama adalah di tahun 1985 yang didistribusikan lewat CompuServe. Saat ini, webcomic mulai keluar dari Web dan berpindah ke media sosial dan perangkat seluler. Banyak pengarang webcomic menggunakan berbagai aplikasi (Garrity, 2011).

Salah satu platform webcomic yang paling besar saat ini adalah LINE Webtoon, yang baru saja masuk ke market bahasa Inggris 4 tahun lalu. Aplikasi ini pertama diluncurkan pada tahun 2005 oleh NAVER dari Korea Selatan, sebagai sebuah platform terbuka di mana kreator bisa self-publish. Setelah modelnya disempurnakan, LINE Webtoon diekspor secara global di tahun 2014. Faktor utama popularitas Webtoon adalah formatnya, dimana chapter webcomic biasanya mencakup beberapa halaman, webtoon adalah sebuah strip vertikal yang panjang. Jika pembaca menggunakan smartphone, format ini membuat membaca webtoon sangat mudah dengan cara di-scroll. Bahkan juga ada beberapa webtoon yang menggunakan animasi atau soundtrack. Selain LINE Webtoon juga ada beberapa platform komikdigital lain dengan karakteristiknya masing-masing, antara lain Tapastic dan Hiveworks (Rawhani, 2018).

\section{Agenda Sustainability dalam Desain}

Istilah sustainability artinya kemampuan untukmeneruskan, untuk bertahan secara berkelanjutan. Agenda sustainability modern biasanya merujuk pada pengembangan yang sustainable, di mana pertumbuhan ekonomi dan gaya hidup modern dapat dicapai sambil juga mempertahankan keadaan bumi dan lingkungan hidup. Dalam desain salah satu istilah terkait sustainability adalah green design, yang artinya sejak pertama kali digunakan oleh komunitas desain di awal tahun 1990-an, telah menjadi bermaknafokus terhadap sebuah isu, atau dampak ekologis dari sebuah aspek desain, contohnya material dan konsumsi energi.

Contoh media desain yang mendorong agenda sustainability berbasis narasi, antara lain dalam buku cerita anak The Lorax oleh Dr. Seuss, novel grafis I'm Not a Plastic Bag, komik
Swamp Thing dan Man Thing dan film Spirited Away. Media-media tersebut mengandung pesan sustainability dalam narasi yang ditampilkan.

\section{Tinjauan Tentang Limbah Cair Industri Fashion}

Proses pembuatan tekstil sebelum menjadi kain yang dapat dibuat menjadi pakaian perlu melewati beberapa tahap. Dan dari tahapan tersebut yang menghasilkan banyak limbah cair adalah tahap dyeing dan finishing. Menurut Kadolph (2010), finishing adalah proses yang dilakukan pada fiber, benang, atau kain baik sebelum atau sesudah produksi kain untuk mengubah penampilannya.

Dyeing adalah pemberian warna dalam produksi kain. Warna selalu merupakan bagian penting dalam tekstil.Hingga 1856, tanaman, serangga, dan mineral digunakan sebagai sumber dye alami. Saat William Henry Perkin menemukan mauve, dye sintetis pertama, terlahirlah sebuah industri baru yaitu dyeing sintetis. Sekarang ada ratusan pilihan colorant yang dapat digunakan.

Pabrik tekstil membuang jutaan galon air limbah yangberbahaya, yang mengandung warna dan bahan kimia dari proses dyeing serta finishing. Limbah ini mengandung sulfur, naftol,dye yang tidak larut air, zat nitrat, asam asetat, sabun, senyawa kromium, merkuri, nikel, kobalt, dan bahan bantu kimia lain, sehingga membuat limbah ini bersifat sangat beracun. Bahan kimia berbahaya lainnya bisa berupa zat dye fixing yang berbasis formaldehida, softener yang berbasis hidrokarbon, dan zat kimia pewarna yangtidak biodegradable. Dan seringnya limbah inimemiliki temperatur dan $\mathrm{pH}$ yang tinggi, sehingga bersifat merusak lingkungan perairan (Kant, 2012). Menurut Kadolph (2010), material dengan BOD dan COD yang tinggi membuat lingkungan yang tidakbersahabat untuk tanaman dan binatang perairan, dan menyebabkan masalah dalam penggunaan air tersebutdi masa depan.

Menurut Kant (2012), bahan koloid serta warna dan buih berminyak membuat air limbah menjadi keruh dan berbau busuk. Selain itu, juga mencegah cahaya matahari, yang diperlukan dalam fotosintesis, untuk tembus ke dalam perairan. Hal ini mempengaruhi mekanisme pemindahan oksigen antara air dan udara. Kekurangan jumlah oksigen yang terlarut dalam air ini adalah dampak limbah tekstil yang paling serius, karena pentingnya 
oksigen dalam kehidupan bawah air. Selain itu, hal ini juga mengganggu proses pemurnian diri dari air. Ditambah lagi jika air tercemar ini mengalir ke tanah, kemudian menyumbat poripori tanah sehingga mengurangi kesuburan tanah tersebut. Tekstur tanah menjadi keras dan akar tanaman tidak dapat tembus ke dalam tanah.

Air limbah yang mengalir di saluran pembuangan dapat mengkorosi pipa selokan, dan jika dibiarkan mengalir ke sungai dapat memengaruhi kualitas air minum sehingga membuatnya tidak layak untuk dikonsumsi manusia. Air tercemar juga bisa menjadi tempat berkembangnya bakteri dan virus.

Air limbah juga memiliki dampak yang signifikan dalam kerusakan lingkungan dan penyakit manusia. Sekitar $40 \%$ dari pewarna yang digunakan secara global mengandung klorin yang terikat secara organik, sebuah zat yang dikenal bersifat karsinogen (menyebabkan kanker). Zat-zat kimia juga dapat menguap ke udara yang kita hirup, atau dapat diserap melalui kulit dan menjadi reaksi alergi dan dapat membahayakan seorang anak sebelum lahir.

\section{Pembuangan Limbah Cair Industri Fashion di Indonesia}

Dalam melakukan pembuangan limbah, harus memenuhi baku mutu air limbah sesuai dengan Peraturan Menteri Lingkungan Hidup Republik Indonesia Nomor 5 Tahun 2014 tentang Baku Mutu Air Limbah. Sesuai pada Tabel 1, setiap zat-zat kimia memiliki standar masing-masing untuk kadar volume dan bebannya untuk dapat dibuang secara legal (Menteri Lingkungan Hidup Republik Indonesia, 2014). Sedangkan untuk konsekuensinya, menurut UU 32/2009, melakukan dumping limbah ke lingkungan hidup tanpa izin dipidana penjara paling lama 3 tahun dan denda paling banyak Rp 3 miliar. (Hutomo, 2018)

\section{Contoh Kasus Pembuangan Limbah Industri Tekstil di Indonesia}

Pembuangan limbah industri tekstil di Indonesia yang paling signifikan adalah di sungai Citarum, Jawa Barat, yang dikenal sebagai sungai terkotor di Indonesia. Padahal, sungai ini sumber air bersih untuk $80 \%$ warga DKI Jakarta, dan juga digunakan untuk mengairi 420.000 ha sawah dan menghasilkan 1.880 MW listrik untuk daerah Jawa dan Bali.
Namun, sungai ini dicemari limbah cair industri sebanyak 349.000 ton per hari (Satrianegara, 2018).

Tabel 1. Permen LH No. 5 Tahun 2014 tentang Baku Mutu Air Limbah Industri Tekstil

\begin{tabular}{lcc}
\hline \multicolumn{1}{c}{ Parameter } & $\begin{array}{c}\text { Kadar Paling } \\
\text { Tinggi (mg/L) }\end{array}$ & $\begin{array}{c}\text { Beban Pencemaran } \\
\text { Paling Tinggi } \\
\text { (kg/ton) }\end{array}$ \\
\hline BOD5 & 60 & 6 \\
COD & 150 & 15 \\
TSS & 50 & 5 \\
Fenol Total & 0.5 & 0.05 \\
Krom Total (Cr) & 1,0 & 0,1 \\
$\begin{array}{l}\text { Amonia Total } \\
\text { (NH3-N) }\end{array}$ & 8,0 & 0,8 \\
$\begin{array}{l}\text { Sulfida } \\
\text { (sebagai S) }\end{array}$ & 0,3 & 0,03 \\
Minyak danLemak & 3,0 & 0,3 \\
pH & $6,0-9,0$ & \\
Debit Limbah & 100 m ${ }^{3 / \text { ton produk }}$ \\
Paling Tinggi & tekstil & \\
\hline
\end{tabular}

Sumber: Menteri Lingkungan Hidup Republik Indonesia (2014). Peraturan Menteri Lingkungan Hidup Republik Indonesia Nomor 5 Tahun 2014 Tentang Baku Mutu Air Limbah.

Lebih dari 2.000 pabrik ada di daerah aliran sungainya, dengan 447 di antaranya dari industri pakaian dan tekstil. Selama puluhan tahun, limbah cair tanpa regulasi telah dibuang ke dalam sungai karena kurang ketatnya peraturan dari pemerintah, bahkan setelah penelitian menunjukkan tingkat polusi tinggi di air dan tanah yang dapat berdampak pada kesuburan tanah dan produksi makanan. Padahal dulu, sebelum perusahaan manufaktur tekstil dan lainnya berkembang pesat di Indonesia di akhir tahun 1970-an, sungai Citarum keadaannya baik, penuh dengan kehidupan.

Mengenai polusi di sungai Citarum secara keseluruhan, ada 500.000 orang yang terkena dampak secara langsung, sementara 5 juta orang terpengaruh secara tidak langsung (Martinez, 2017). Di tahun 2020 ini, tepatnya pada 25 dan 26 Februari 2020, juga ada gugatan perdata oleh Kementerian Lingkungan Hidup dan Kehutanan (KLHK) terhadap dua perusahaan tekstil yang terbukti mencemari lingkungan DAS Citarum. Perusahaan tersebut yaitu PT Kamurga Kurnia Textile Industri (KKTI), yang dihukum membayar ganti rugi Rp 4,25 miliar dan PT How Are You Indonesia (HAYI), yang dihukummembayar Rp 12,013 miliar (Arumingtyas, 2020). Polusi dari limbah industri tekstil ini juga telah berdampak di Surabaya. Dari hasil pantauan inspeksi 
mendadak di tahun 2017 oleh Tim Patroli Air Jatim, ditemukan PT Gaweredjo, sebuah pabrik pewarnatekstil, yang membuang limbah cair tanpa diolah.Limbah tersebut memiliki $\mathrm{pH}$ melebihi baku mutu,sehingga banyak ikan kecil yang munggut, bahkanmati. (Pabrik Pewarna Kain Gaweredjo Diduga Cemari Kali Surabaya, 2017).

Sejak September 2018, Pemerintah Kota (Pemkot) Surabaya resmi melarang perusahaan tersebut beroperasi. Namun, setelah diadakan lagi inspeksi mendadak di bulan September 2019, ditemukan cairanhitam berbau menyengat yang mengalir dari lubang pembuangan pabrik, menunjukkan bahwa perusahaan masih beraktivitas. Sample air yang diambil dikirimke laboratorium, dan jika terbukti tidak sesuai standar baku mutu, akan dikenakan sanksi yang diserahkan pada Pemkot Surabaya (Produksi Tanpa Izin, PT Gaweredjo Kembali Buang Limbah ke Kali Surabaya, 2019).

\section{Analisa Survei Lapangan}

Dari hasil pembagian survei yang dilakukan pada hari Rabu, 25 Maret 2020 sampai Sabtu, 28 Maret 2020 terhadap responden menunjukkan bahwa kebanyakan tidak tahu seperti apa saja dampak negatif industrifashion. Saat ditanyakan apa saja dampak negatif tersebut, dari 42 responden 23 orang menjawab tidak tahu, jawaban dari 11 orang termasuk sampah darikain sisa atau baju bekas, 10 orang menyebutkan pencemaran/limbah, dan 4 orang menyebutkan upah/kesejahteraan pekerja/buruh. Hal ini membuktikan bahwa kebanyakan masyarakat tidak tahu mengenai dampak negatif industri fashion.

Saat ditanyakan apa yang diketahui tentang limbah cair industri fashion, 26 orang menjawab tidak tahu/kurang tahu dan hanya 9 orang yang menyebutkan tentang pewarnaan tekstil, membuktikan bahwa kebanyakan masyarakat tidak tahu mengenai pewarnaan tekstil sebagai bagian utama limbah cair industri fashion.

Selanjutnya, survei membuktikan bahwa kebanyakan masyarakat tidak pernah berupaya melakukan sesuatu untuk meminimalkan dampak negatif industri fashion. Dari yang menjawab pernah, jawaban paling banyak saat ditanya apa yang pernah dilakukan adalah mendonasikan baju bekas, yaitu 8 dari 19 orang.
Dari 11 orang yang menjawab pernah inginmelakukan sesuatu, terbukti bahwa 10 orang mengatakan bahwa tidak jadi melakukannya karena tidak tahu apa yang bisa dilakukan, sedangkan 1 orangmenjawab karena belum paham. Sedangkan dari 12 orang yang menjawab tidak pernah ingin melakukan sesuatu, 9 orang mengatakan bahwa mereka tidak pernah berniat karena tidak terpikir, 2 orang merasa bahwa melakukan perubahan sebagai 1 orang saja tidak ada gunanya, dan 1 orang merasa bahwa semuanya tergantung penjual karena konsumen tidak bisa membedakan asal-usul barang.

\section{Konsep Perancangan}

Perancangan komik ini bertujuan untuk menunjukkan kepada target audiens dampak negatif dari industriproduksi fashion, terutama dalam bidang polusi/limbah cair. Harapannya, melihat bahwa ada hal yang dapat dilakukan secara pribadi untuk membawa perubahan, bisa menjadi harapan yang dapat mendorong pembaca untuk mencoba mengubah kebiasaan konsumsi fashion mereka.

\section{Strategi Kreatif}

Menggunakan komik sebagai narasi dengan simbolisme fantasi berupa seorang mermaid yang menggambarkan manusia dan kehidupan bawah air yang menjadi korban perbuatan manusia sendiri. Hal ini memperkuat ide bahwa "monster"-nya di sini adalah manusia dan perbuatannya yang merusak alam dan bahkan membahayakan manusia lain. Karakter yang melaporkan tindakan buruk perusahaan dan membantu mermaid yang terluka menunjukkan kepada pembaca bahwa satu orang saja bisa membawa dampak dan perubahan positif yang signifikan.

\section{Target Audience}

Perempuan umur 17-25 tahun yang feminin, suka berpenampilan cantik melalui baju dan makeup. Selain itu juga suka menggunakan smartphone, khususnya untuk bermain sosial media dan membaca webtoon.

\section{Format Komik}

Komik yang dirancang berupa webcomic yang diterbitkan melalui aplikasi LINE Webtoon. Komik adalah suatu cerita panjang dengan total 7 episodeberkelanjutan, beserta 2 episode tambahan sebagai media pendukung. 


\section{Judul Komik}

Judul utama dari webtoon ini adalah " $A$ Mermaid's Anguish" memberi kesan yang agak gelap sesuai nuansa cerita yang sedih, dan sebagai judul yang cocok dengan gaya cerita dan visual yang terinspirasi dari novel grafis independen barat.

\section{Sinopsis}

Komik ini menceritakan tentang Nora, seorang aktivisyang sedang membuat video dokumenter. Suatu hari, saat merekam video di sungai tempat pembuangan limbah pabrik pewarna tekstil, ia menemukan seorang mermaid tidak sadarkan diri, yang sakit akibat limbah pabrik tersebut. Cerita mengikuti perjalanan Nora menolong si mermaid serta berusaha menanggulangi tindakan perusahaan itu.

\section{Gaya Visual}

Gaya visual ilustrasi komik adalah gaya pribadi yang terpengaruh dari novel grafis independen barat. Gaya ilustrasi bertekstur menyerupai ilustrasi manual. Tipografi yang digunakan juga tulisan tangan sendiri. Tone warna yang digunakan adalah warna muted dengan beberapa warna aksen yang vibrant.

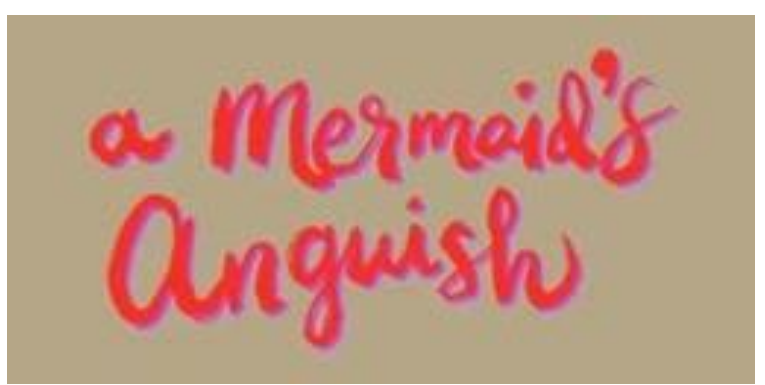

Gambar 1. Tipografi Judul

\section{Hasil Perancangan}

\section{Desain Karakter}

Tokoh utama dari cerita adalah Nora, seorang aktivis yang sangat peduli terhadap masalahmasalah sosial, dan gigih dalam mempertahankan integritas dan prinsip moralnya. Ia sering berinisiatif untuk melakukan perbuatan konkret untuk mendukung tujuan masalah sosial yang dihadapi, salah satunya dengan membuat film-film dokumenter. Nora berpenampilan santai, dengan rambut pendek messy, hampir menyerupai beberapa elemen subkultur hipster. Untuk menggambarkan sifatnya yang peduli terhadap sustainability, menggunakan pakaian yangdibeli melalui thrifting baju bekas. Karena itu, gaya berpakaiannya seperti biasanya "thrift fashion" yang bernuansa vintage.

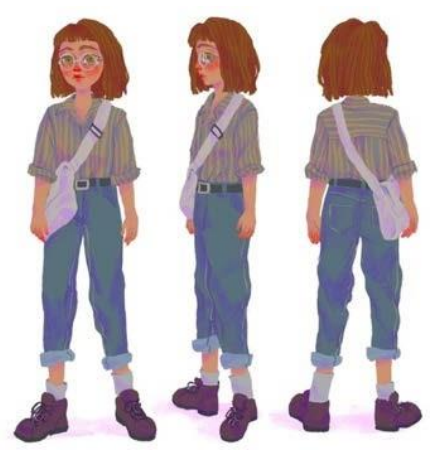

Gambar 2. Karakter Nora

Mermaid sifatnya naif, tidak berpikir panjang, danimpulsif, tapi pengertian. Mermaid melambangkan alam yang meski tidak salah apa-apa, tetap dirusak oleh manusia. Karena itu karakter merupakan anak kecil yang polos, dan menggunakan warna-warna relatif muda (pastel) untuk menggambarkan kemurniannya. Untuk menekankan bahwa karakter bukan manusia, diberi warna kulit ungu dan desain mata yang berbeda.

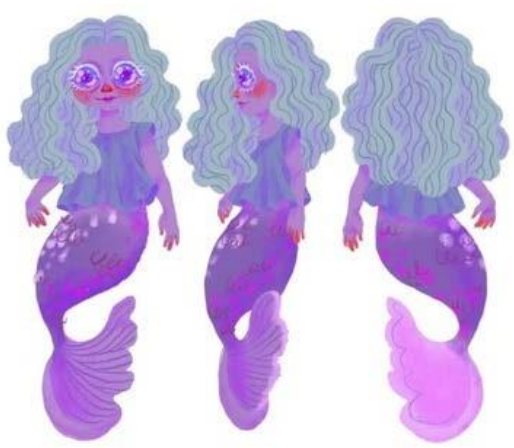

Gambar 3. Karakter Mermaid

Lukas adalah tetangga Nora, seorang dokter umum yang memiliki sebuah rumah sakit/ klinik kecil. Tampilannya lembut dan ramah. Agak nerdy, ditunjukkan dengan gaya berpakaian dan kacamatanya.

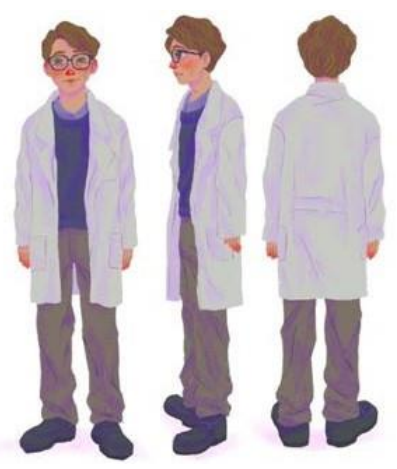

Gambar 4. Karakter Lukas 
Direktur adalah pemimpin dari pabrik pewarna tekstil, sifatnya dingin, merasa bahwa profit adalah segalanya, lebih penting dari apa pun. Gaya berpakaiannya selalu menggunakan jas formal yang mahal.

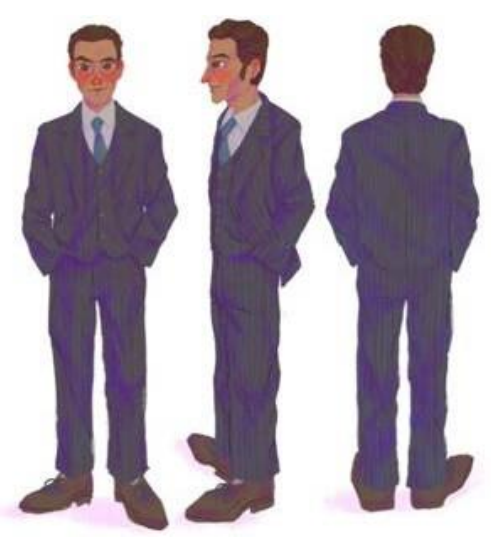

Gambar 5. Karakter Direktur

Megan adalah sekretaris direktur, yang cakap dalam pekerjaannya, teliti dan terorganisir. Untuk menunjukkan sikap tegasnya dibuat tatapan matanya yang tajam.

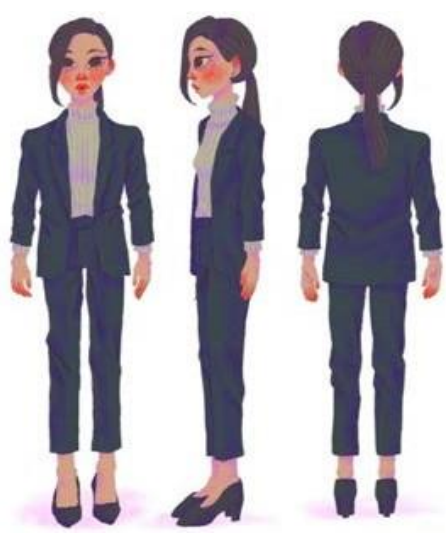

Gambar 6. Karakter Megan

\section{Thumbnail Webtoon}

Thumbnail serial webtoon ada dua macam, yaitu thumbnail serial dan thumbnail tiap episode. Subjek yang digambarkan dalam thumbnail serial adalah karakter mermaid yang dilihat dari refleksi lensa kamera. Komposisinya dibuat close-up pada wajah karena tampilan thumbnail di pencarian judul ukurannya kecil, terutama jika dilihat menggunakan smartphone. Sedangkan subjek yang digambarkan pada thumbnail tiap episode yaitu artwork yang diambil dari komik episode itu sendiri yang paling cocok untuk mewakili ceritanya.

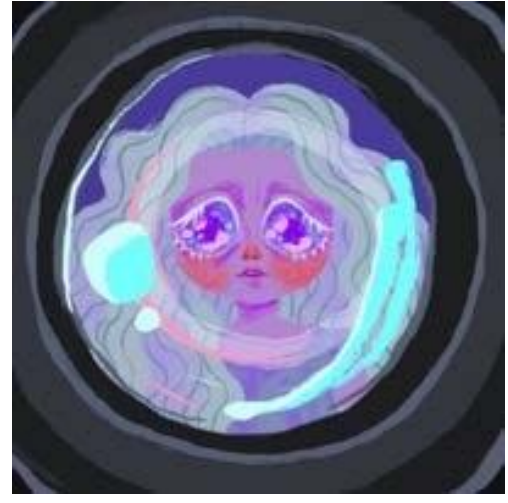

Gambar 7. Thumbnail Serial Webtoon

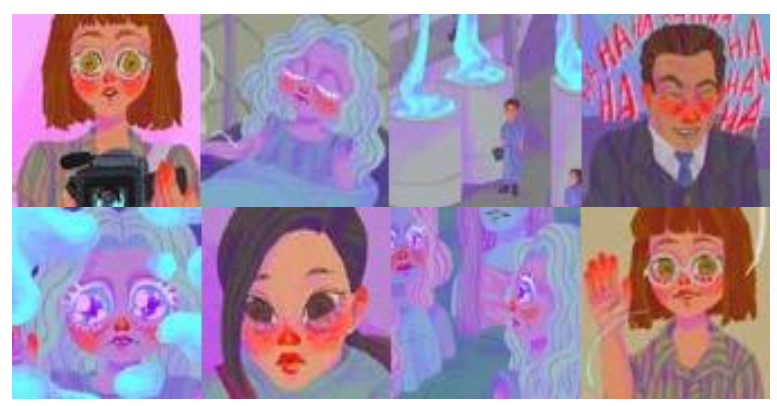

Gambar 8. Thumbnail Episode Webtoon

\section{Layout}

Layout komik adalah memanjang secara vertikal yang dibaca dengan cara scrolling. Sebelum diunggah, komik dipotong menjadi ukuran 800 x 1280 px dengan format gambar JPG.

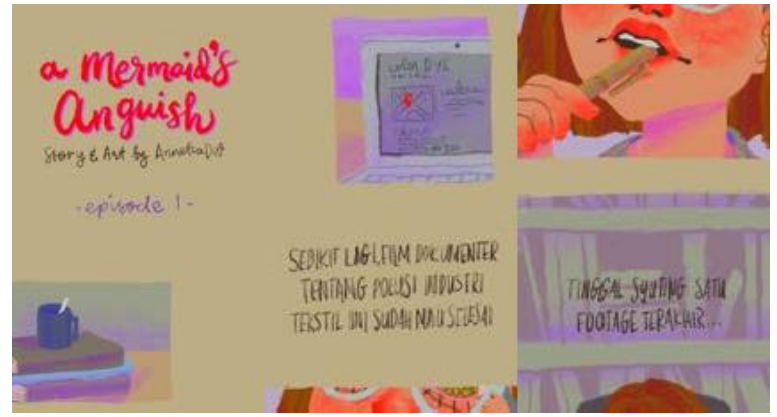

Gambar 9. Layout Komik Setelah Dipotong

\section{Media Pendukung}

Media pendukung utama adalah akun Instagram, yang digunakan untuk memberikan update kepada pembacadan juga untuk menarik perhatian pembaca baru. Selain itu akun Instagram ini juga digunakan sebagai tempat menampilkan pameran online data dan informasi yang berhubungan dengan topik. 


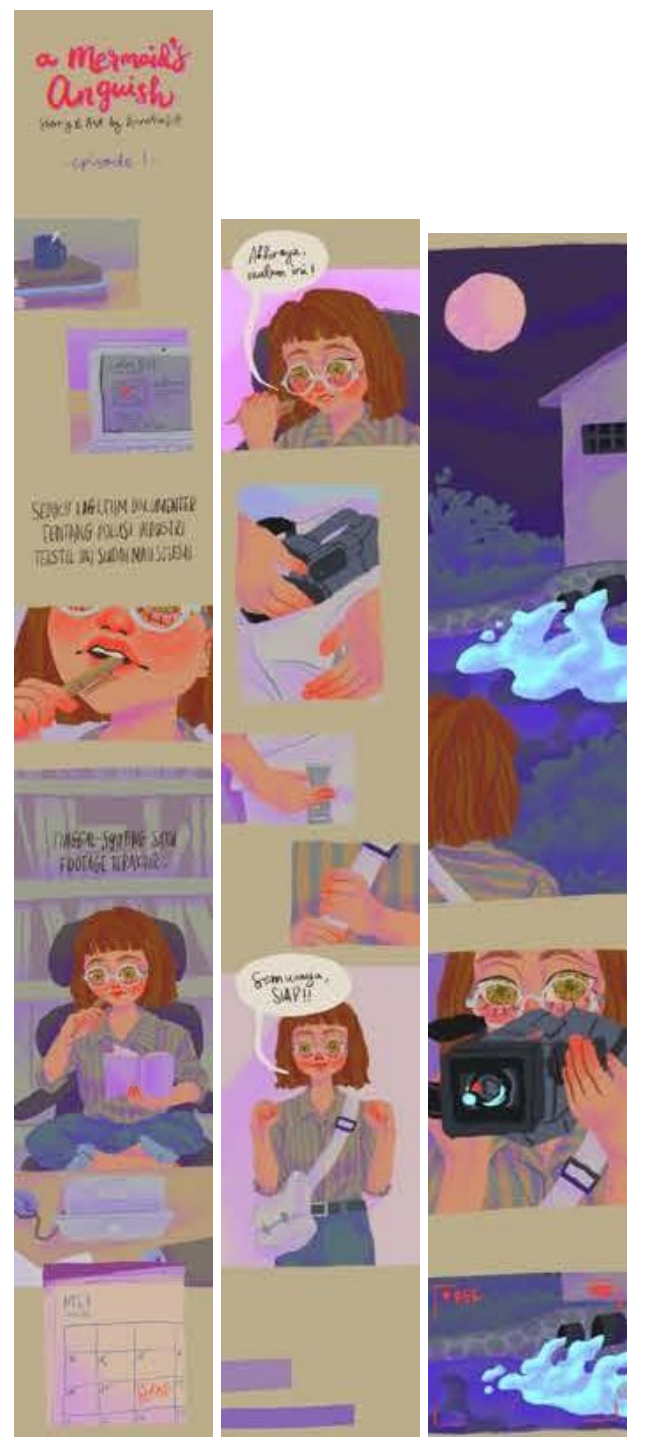

Gambar 10. Layout komik memanjang, contoh desain final episode 1
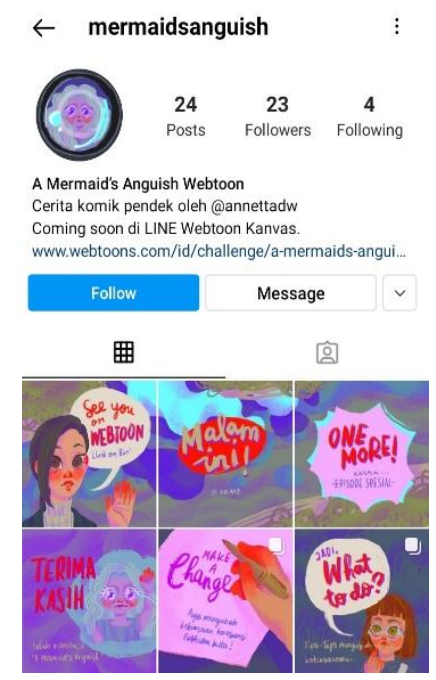

Gambar 11. Akun Instagram @mermaidsanguish

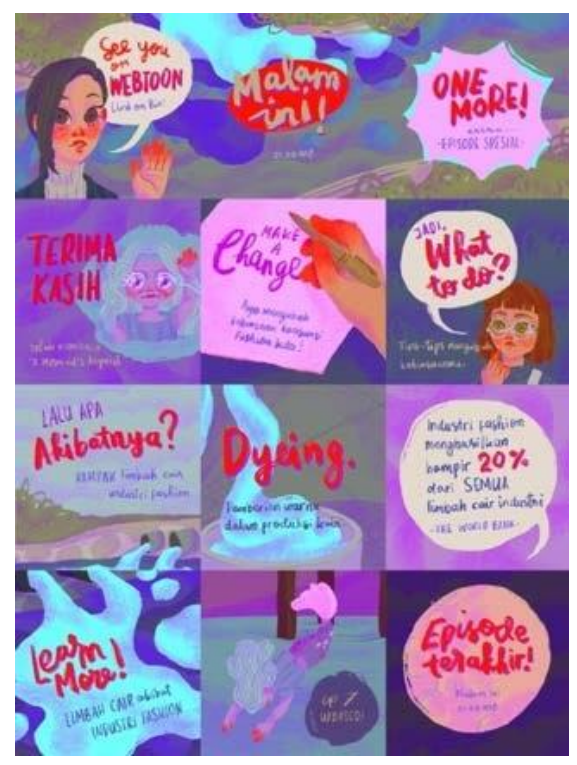

Gambar 12. Post Instagram Sebagai Pameran Online
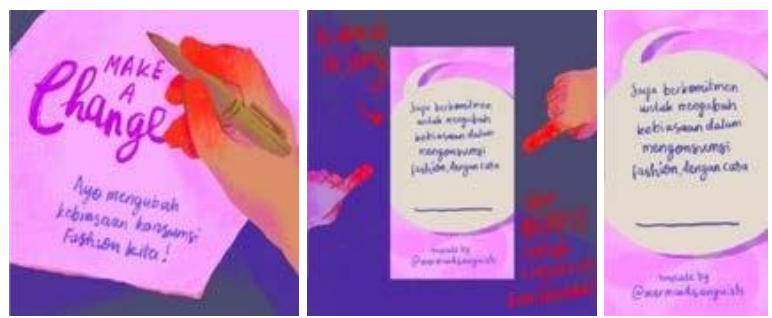

Gambar 13. Desain Instagram Story Interaktif

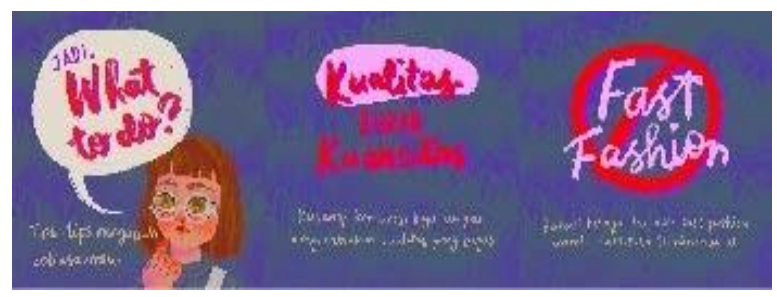

Gambar 14. Contoh Desain Multiple Post

Untuk beberapa post di mana informasi yang perlu disampaikan cukup banyak, dipergunakan fitur multiple post sehingga cukup untuk menyampaikan informasi tersebut. Selain itu juga dibuat elemen interaktif yaitu template Instagram story yang dapat di-repost oleh audiens sebagai tanda janji dan komitmen untuk mengubah kebiasaan konsumsi fashion mereka.

Media pendukung berikutnya adalah merchandise yang dapat digunakan sasaran perancangan, antara lain kaos, tote bag, pin, dan sticker. Selain itu juga dibuat poster dan $x$ banner sebagai media promosi. 

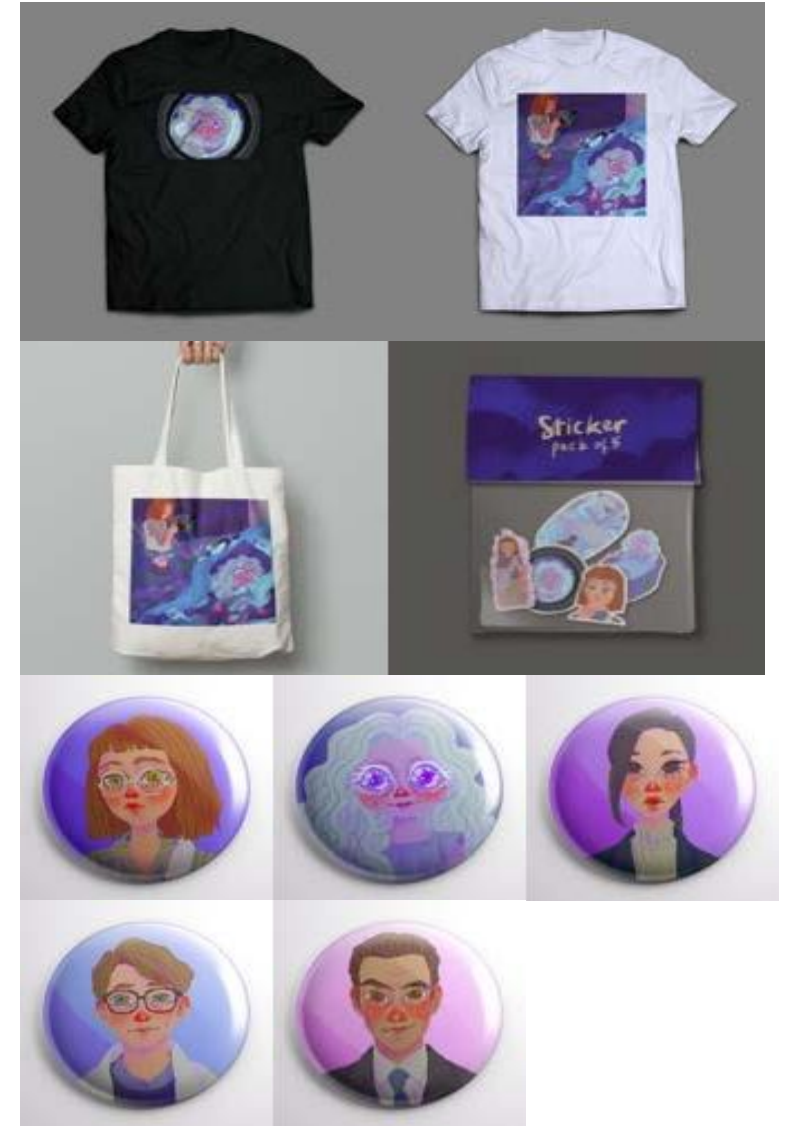

Gambar 15. Desain Merchandise

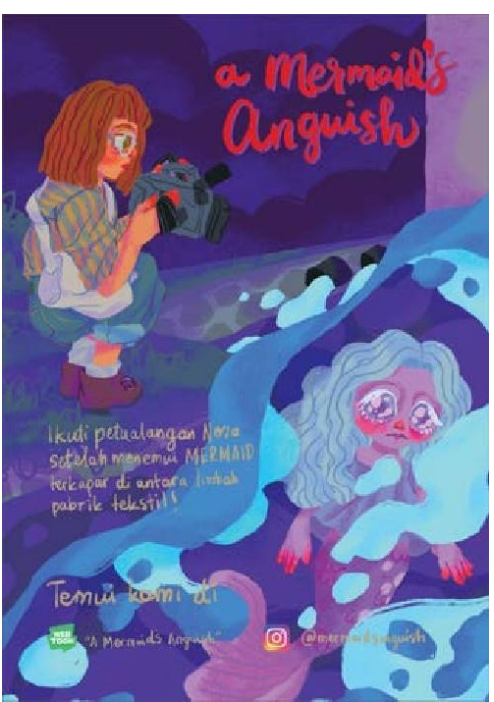

(a)

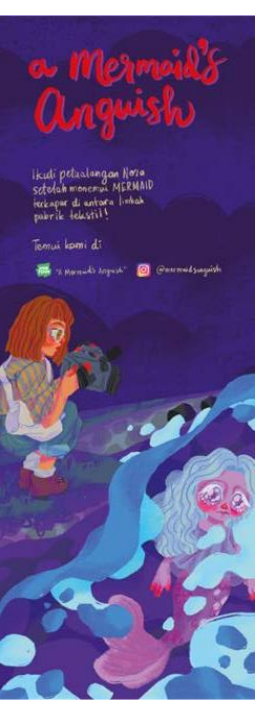

(b)
Gambar 16. (a) Desain Poster, (b) Desain $x$-banner

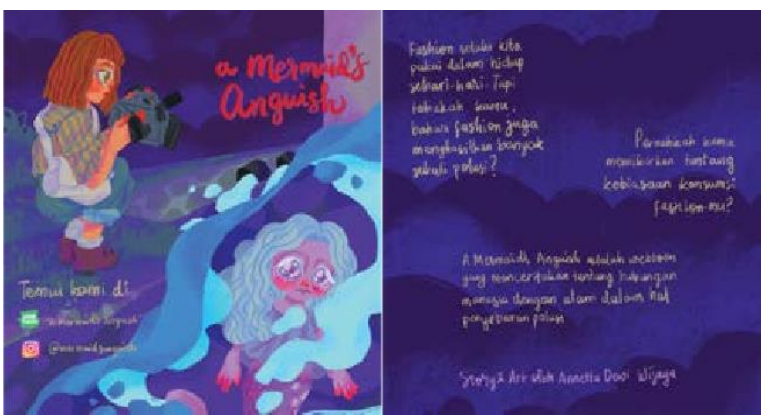

Gambar 17. Desain Katalog

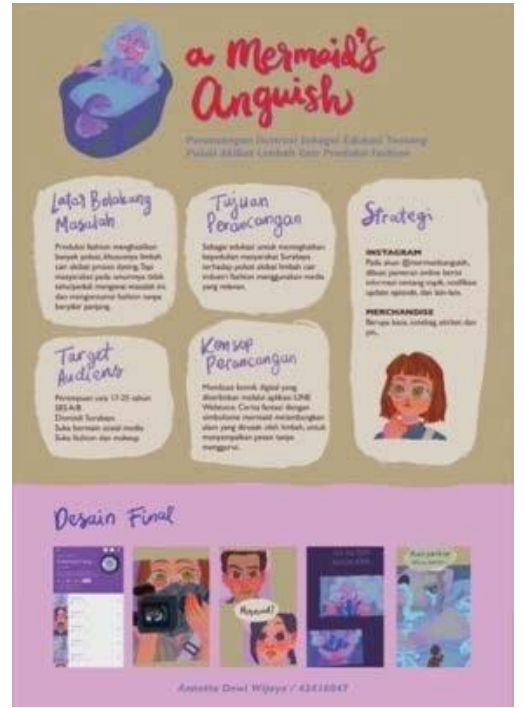

Gambar 18. Desain Poster Konsep

\section{Kesimpulan}

Industri fashion memiliki dampak yang sangat besar pada lingkungan hidup. Khususnya, proses dyeing dalam produksi fashion adalah kontributor yang signifikan pada pencemaran air. Di Indonesia sendiri, sudah ada Sungai Citarum yang sangat tercemar akibat dibuangnya limbah cair pabrik tekstil yang tidak sesuai aturan. Bahkan di Surabaya pun juga ada ditemukan pabrik pewarna kain yang membuang limbah di Kali Surabaya tanpa diolah. Meski keadaannya sudah cukup buruk, kebanyakan masyarakat tidak tahu banyak mengenai masalah ini dan tidak peduli sehingga mengonsumsi fashion sembarangan tanpa memikirkan dampaknya pada lingkungan. Karena itu, diperlukan media yang dapat meningkatkan kepedulian masyarakat pada topik ini. Untuk itu, penting adanya cerita yang dapat menyentuh hati mereka dan menginspirasi untuk melakukan sesuatu. Karena itu cerita dibuat fantasi dengan mempergunakan bermacam-macam simbolisme, dengan tokoh utama berupa tokoh idealistis yang bisa menjadi teladan bagi pembaca. Diharapkan, setelah membaca webtoon dan melihat pameran online di Instagram, audiens bisa terinspirasi untuk juga mengambil tindakan dan mengubah kebiasaan mereka dalam konsumsi fashion. Webtoon ini diterbitkan di aplikasi LINE Webtoon yang gratis dan mudah untuk diakses sehingga dapat berpotensi mencapai audiens yang luas.

Perancangan ini terdiri dari tujuh episode dan satu episode tambahan untuk mengarahkan pembaca ke Instagram. Sejak pertama kali diunggah pada tanggal 28 Mei 2020 hingga 
tanggal 17 Juni 2020, webtoon ini sudah memiliki 1500 pembaca, 67 orang yang menambahkan sebagai favorit, dan mencapai rating 8,94. Komentar-komentar yang diberikan pembaca secara keseluruhan positif dan membangun. Kebanyakan mengomentari visualnya, tapi ada juga beberapa yang juga memberi tanggapan tentang ceritanya. Dan untuk elemen interaktif pada akun Instagram, ada yang berpartisipasi dan membuat komitmen mengubah kebiasaan meski baru sedikit. Karena itu, penulis menyimpulkan bahwa meskiperancangan sudah berhasil tapi belum secara maksimum.

Untuk berikutnya, perancangan ini dapat berkelanjutan dengan membuat webtoon dan sosialmedia yang lebih memfokuskan kepada pengalaman dalam menerapkan prinsip sustainable fashion dalam kehidupan seharihari, sambil tetap memberi tips-tips untuk membantu audiens ikut mengubah kebiasaan konsumsi fashion-nya menjadi lebih sustainable.

\section{Daftar Pustaka}

Arumingtyas, L. (2020, March 4). Dua Perusahaan Cemari DAS Citarum Kena Hukum Rp16,26 Miliar. Retrieved from https://www.mongabay.co.id/2020/03/04/dua -perusahaan-cemari-das-citarum-kenahukum-rp1626-miliar/

Chick, A., \& Micklethwaite, P. (2011). Design for Sustainable Change. Lausanne, Switzerland: AVA Publishing SA.

Clark, M. (2011). Handbook of Textile and Industrial Dyeing. Vol. 1. Cambridge, United Kingdom: Woodhead Publishing.

Fashion's Environmental Impact. (2017). Retrieved from https://www.sustainyourstyle.org/oldenvironmental-impacts

Garrity, S. (2011, July 15). The History of Webcomics. Retrieved from http://www.tcj.com/thehistory-of-webcomics/

Hethorn, J. \& Ulasewicz, C. (2015). Sustainable Fashion: What's Next?. New York, NY: Bloomsbury.

Houston, G. (2016). Illustration That Works: Professional Techniques for Artistic \& Commercial Success. New York, NY:MonacelliStudio.

Hutomo, D. (2018, December 20). Sanksi Membuang Limbah ke Lingkungan Laut Tanpa Izin. Retrieved https://www.hukumonline.com/klinik/detail/ulasan/ lt5bc2bcf68f29f/sanksi-membuang-limbahke-lingkungan-laut-tanpa-izin/

Illustrate. (n.d.). Retrieved from https://www.vocabulary. com/dictionary/illustrate

Kadolph, S. J. (2017). Textiles. Upper Saddle
River,NJ: Pearson Education Inc.

Kant, R. "Textile Dyeing Industry an Environmental Hazard.” Natural Science, vol. 04, no. 01, 2012, pp. 22-26., doi:10.4236/ns.2012.41004.

Lebih dari 64 Industri Tekstil Diduga Buang Limbahke Citarum. (2018). Retrieved from https://www.cnnindonesia.com/ekonomi/201 80111214632-92-268281/lebih-dari-64industri-tekstil-diduga-buang-limbah-ke-citarum

Limbah Cair Industri. (2015, October 26). Retrieved from http://www.saka.co.id/newsdetail/limbah-cair-industri

Male, A. (2007). Illustration: A Theoretical \& Contextual Perspective. Lausanne, Switzerland: AVA Publishing SA.

Martinez, S. (2017, May 29). Textile factories in Indonesia pollute water in Cikijing River, tributary of Citarum River, Indonesia. Retrieved from https://ejatlas.org/conflict/ptkahatex-pt-insan-sandan-internusa-and-ptfive-star-textile

McCloud, S. (1994). Understanding Comics: The Invisible Art. New York, NY: William Morrow.

Menteri Lingkungan Hidup Republik Indonesia. (2014). Peraturan Menteri Lingkungan Hidup Republik Indonesia Nomor 5 Tahun 2014 Tentang Baku Mutu Air Limbah. Retrieved http://neo.kemenperin.go.id/files/hukum/17 \%20Permen\%20LH\%20th\%202014\%20No.\% 2005\%20Baku\%20Mutu\%20Air\%20Limbah .pdf

Pabrik Pewarna Kain Gaweredjo Diduga Cemari Kali Surabaya. (2017, December 28). Retrieved http://infopublik.id/read/240846/pabrikpewarna-kain-gaweredjo-diduga-cemarikali-surabaya.html

Produksi Tanpa Izin, PT Gaweredjo Kembali Buang Limbah ke Kali Surabaya. (2019). Retrieved http://kominfo.jatimprov.go.id/read/umum/ produksi-tanpa-izin-pt-gaweredjo-kembalibuang-limbah-ke-kali-surabaya-

Rawhani, A. (2018, July 31). The Brave New World of Webcomics: Making Sense of Platforms, Publishers, and A Snowballing Popularity. Retrieved https://brokenpencil. com/features/the-brave-new-world-ofwebcomics-making-sense-of-platformspublishers-and-a-newfound-popularity/

Satrianegara, R. (2018, April 6). Citarum Dicemari Limbah Industri 349.000 Ton Setiap Hari. Retrieved https://www.cnbcindonesia.com/ news/20180406133932-4-9961/citarumdicemari-limbah-industri-349000-tonsetiap-hari

Thomas, D. (2019). Fashionopolis: The Price of Fast Fashion and the Future of Clothes. New York, NY: Penguin Press. 